ENTREPRENEURSHIP AND SUSTAINABILITY ISSUES

ISSN 2345-0282 (online) http://jssidoi.org/jesi/ 2019 Volume 7 Number 1 (September)

http://doi.org/10.9770/jesi.2019.7.1(34)

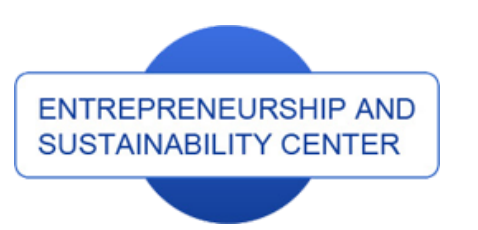

Publisher

http://jssidoi.org/esc/home

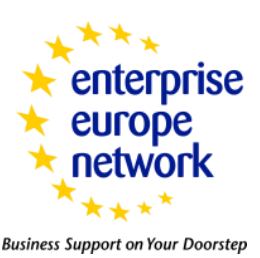

CASPA

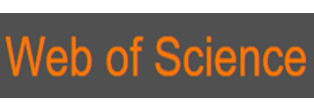

Clarivate
Analytics

\title{
MATHEMATICAL MODEL OF OPTIMIZING THE BALANCE SHEET STRUCTURE OF THE RUSSIAN BANKING SYSTEM WITH ALLOWANCE FOR THE FOREIGN EXCHANGE RISK LEVELS
}

\author{
Karine Barmuta ${ }^{1}$, Vadim Ponkratov", Maksim Maramygin ${ }^{3}$, Nikolay Kuznetsov ${ }^{4}$, Vitali Ivlev ${ }^{5}$, Marina \\ Ivleva $^{6}$ \\ ${ }^{1}$ Don State Technical University, 1 Gagarina Sq., Rostov-on-Don, 344000, Russian Federation \\ ${ }^{2}$ Financial University under the Government of the Russian Federation, 49 Leningradsky Pr., Moscow, 125993, Russian \\ Federation \\ ${ }^{3}$ Ural State University of Economics, 628 Marta St., Yekaterinburg, 620144, Russian Federation \\ ${ }^{4}$ State University of Management, 99 Ryazanskiy prospect, Moscow, 109542, Russian Federation \\ ${ }^{5}$ Bauman Moscow State Technical University, 5/1 2-nd Baumanskaya St., Moscow, 105005, Russian Federation \\ ${ }^{6}$ Plekhanov Russian University of Economics, 36 Stremyanny lane, Moscow, 117997, Russian Federation
}

\section{E-mails: ${ }^{2 *}$ ponkratovvadim@yandex.ru (Corresponding author)}

Received 11 February 2019; accepted 10 July 2019; published 30 September 2019

\begin{abstract}
Under present-day conditions of significant national currency fluctuations in the Russian Federation, a search for effective methods of foreign exchange risk management in the banking system is being updated. In this regard, development of a mathematical model for optimizing the asset and liability structure in Russian banks with allowance for the foreign exchange risk was the goal of the research. Using a method of regression analysis, a mathematical model has been developed to optimize the balance sheet structure of the banking system based on determining the dependence of net profit on asset and liability figures of the balance sheet, whereby the profit and profitability of banking in foreign currency is maximized. This mathematical optimization model was based on the permissible foreign exchange risk level standards in banking. Statutory financial reporting data of the Russian banking system in the aggregate denominated in foreign exchange (in ruble equivalent) for the period from 01.10.2010 to 01.02.2019 and disaggregated by months were used. The model results for the last three years were compared with the actual data. The model results can help optimize efficient allocation of resources and improve banking foreign exchange risk management policies.
\end{abstract}

Keywords: asset-liability management; foreign exchange risk; foreign currency; ideal planning; modeling, banking system

Reference to this paper should be made as follows: Barmuta, K.; Ponkratov, V.; Maramygin, M.; Kuznetsov, N.; Ivlev, V.; Ivleva, M. 2019. Mathematical model of optimizing the balance sheet structure of the Russian banking system with allowance for the foreign exchange risk levels, Entrepreneurship and Sustainability Issues 7(1): 484-497. http://doi.org/10.9770/jesi.2019.7.1(34)

JEL Classifications: G21, G32, F31, O24 


\section{ENTREPRENEURSHIP AND SUSTAINABILITY ISSUES}

ISSN 2345-0282 (online) http://jssidoi.org/jesi/

2019 Volume 7 Number 1 (September)

http://doi.org/10.9770/jesi.2019.7.1(34)

\section{Introduction}

Today, banks play a crucial role in the national economy as financial intermediaries. Not only the financial system's reliability but also the national economic stability as a whole depends on the level of their financial sustainability and operational efficiency (Halim et al., 2015; Saksonova, 2013; Chunikhin et al., 2019; Kunitsyna et al., 2018). In this regard, the key objective of banking institutions is not only to assess potential risks but also to form a respective mechanism to counteract their negative impact. Being a large and complex system with a huge number of variables, various factors and relationships, financial risk analysis requires quite complex, welladvanced mathematical methods, statistical data processing methods, numerical methods, and computer tools (Mehri \& Jamshidinavid, 2015; Mohammadi \& Sherafati, 2015; Teresienė, 2018; Oleksyk, 2018; Tvaronavičienè et al., 2018; Hilkevics, Semakina, 2019). One of the risks that have adversely affected the financial performance and, consequently, the sustainability of the Russian banking institutions within the specified periods is the foreign exchange risk. In downturns, the exchange rate volatility has sharply increased. Thus, in early 2009, the dollar rose by $48 \%$ compared to the Russian ruble from the same period a year earlier, while in January 2015 the dollar grew by $72 \%$ compared to 2014. Starting from late 2008 and for much of 2009, the banking system demonstrated a violation of a foreign exchange position standard, the maximum value of which was observed in January 2009$34.6 \%$ (at a normal rate of no more than $20 \%$ ), which indicates a high foreign exchange risk. The ruble weakening was observed throughout 2015 , and in early 2016 the dollar rose further by $28.3 \%$ compared to 2015 , while as of 1 January 2019, the dollar grew by $21.7 \%$ compared with the same period a year earlier (The Central Bank of the Russian Federation, 2019a). It should be noted that many countries have faced foreign exchange risks in recent decades. Moreover, the situation is constantly exacerbated by intensified globalization processes. For example, in 2018 the Turkish lira fell by more than 40\%, which, according to Goldman Sachs' analysts, would significantly reduce supplementary capital of banks because the value of their own capital in the national currency was decreasing compared to foreign currency loans while the banks still had to repay the foreign currency debts in the amount of 76 billion dollars (Pitel \& Arnold, 2018). In Russia, the International Monetary Fund (IMF) experts have identified two currency crises-in 1998 and in 2014 (Laeven \& Valencia, 2018).

The current situation necessitates further study of the theoretical and practical foundations for the formation of a risk management system to manage foreign exchange risks in lending institutions based on mathematical modeling, since the existing methods have proved to be inconsistent (Agarana et al., 2014; Bolotov, 2013a, $2013 \mathrm{~b}$ ). One way to solve the problem of foreign exchange risk management can be development of mathematical tools to control bank assets and liabilities, including a foreign currency component. In the most general terms, asset and liability management represents planning of assets and liabilities according to different requirements and the bank management objectives via consolidated balance sheets (a balance method). Asset and Liability Management (ALM) shows the relationship between risk and bank profitability. All financial decisions of a bank are reflected on the balance sheet, which makes it possible to evaluate their effectiveness and risk level (Alhumaidah, 2015; Umarova \& Idirisova, 2015). Asset and liability management strategy refers to mathematical planning that includes various constraints in the form of mathematical equations and takes into account all the relationships between phenomena that must be balanced (Mehrabi, 2014). Recently, in addition to maximizing profits, banking institutions have had to solve problems related to risks, liquidity, social issues, etc. In such cases, researchers recommend using multi-criteria decision-making models, such as a goal-oriented programming model as a multi-criteria decision making model (Khalili, 2007; Izadi et al., 2012; Azizi \& Neisy, 2017). Having regard to the above, development of a mathematical model to optimize the balance sheet structure of the Russian banking system with allowance for the specified level of foreign exchange risk is the major goal of this research. In the furtherance of this goal, the ratios between balance sheet items in the form of financial ratios were primarily determined and then, using a nonlinear programming method, optimal plan (ideal) indicators of the balance sheet structure were calculated. 


\section{ENTREPRENEURSHIP AND SUSTAINABILITY ISSUES}

ISSN 2345-0282 (online) http://jssidoi.org/jesi/

2019 Volume 7 Number 1 (September)

http://doi.org/10.9770/jesi.2019.7.1(34)

\section{Literature review}

In the development of global banking and financial activity, the question of how to manage foreign exchange risks in banking institutions has always been regarded as an important issue because the operation of financial institutions is closely linked to conducting significant quantities of foreign exchange transactions. Today, the banking arsenal avails of the following foreign exchange risk management practices: foreign exchange position management, hedging by means of derivative contracts, Value-at-Risk (VAR) methods, and currency matching. Each of the reviewed management methods has disadvantages: the possibility of breaching risk hedging contracts in the event of a crisis, the need for large amounts of data and complex calculations according to the VAR methods, analysis of foreign exchange position as a whole in terms of total assets and liabilities of a bank rather than on an item by item basis, etc. At the same time, the asset and liability management method to manage foreign exchange risks by means of optimizing the balance sheet structure denominated in foreign currency has not been reflected in the current scientific literature.

A number of authors (Alizadeh et al., 2016; Izadi et al., 2012; Ebrahimi, 2010; Islami et al., 2011; Arewa et al., 2013; Khazri et al., 2018; Dudka, 2006; Umarova \& Idirisova, 2015) in their studies used the asset and liability management method to identify an optimal structure of a bank balance sheet, taking into account different objectives. Thus, using the ALM method and an ideal scheduling model, Alizadeh et al. (2016) optimized bank balance sheet structures through case studies of five banks in order to maximize profits and taking into account the balance sheet risk. In turn, Izadi et al. (2012), using multi-purpose decision-making techniques, made an attempt to optimize balance sheets of commercial banks to maximize the shareholders' wealth. The research results have shown that all the anticipated goals for market risk and deviations from the planned values were fully achieved, with the exception of market risk that was zero. Using a method of hierarchical analysis of an ideal scheduling model for asset and liability management, Ebrahimi (2010) optimized the balance sheet structure of Tejarat bank in accordance with goals such as capital adequacy and liquidity level maximization. In their study, Islami et al. (2011) show that by means of an ideal scheduling model, a bank balance sheet can be structured so that so that it will improve the bank's resource distribution efficiency. Khazri et al. (2018), through the case study of an Iranian bank, using fuzzy hierarchical analysis in conjunction with the ideal scheduling model structured the balance taking into account structural and ideological constraints, as well as legal requirements. The results obtained contribute to a more efficient allocation of bank resources. Dudka (2006) developed a complete asset and liability management model through the case study of a Russian bank, mainly aimed at building such a bank asset and liability structure that would contribute to an increase in the bank's net interest margin. Umarova and Idirisova (2015) in their study suggest optimizing a bank balance sheet, taking into account off-balance assets and liabilities; they also come to the conclusion that banks should make allowance for risks when managing their assets and liabilities but they should never build their strategy on interest rate estimates. Arewa et al. (2013) propose an optimal structure of a bank balance sheet with allowance for the liquidity risk using the ideal scheduling method through the case study of United Bank for Africa (UBA). Alhumaidah (2015) developed two optimization models for the central bank of Saudi Arabia, taking into account an outflow of reserves. Saksonova (2013) proposes to optimize the structure of assets and liabilities through the case studies of Latvian banks to ensure operation profitability and minimize the interest rate risks. Thus, according to the analysis of literary sources, the balance method is the most acceptable method to control assets and liabilities.

\section{Materials and methods}

This study is a practical research that has analyzed the existing part of balance sheet structure of the banking system in the Russian Federation, denominated in foreign currency (in ruble equivalent) and proposed a mathematical model of its optimal structure. The restrictions and requirements presented in the model were developed with due consideration to the opinions of experts and rating agencies (Moody's Investors Service, 2009; Karkowska, 2014; Asian Development Bank, 2015; Xu et al., 2019; Azizi \& Neisy, 2017) who dealt with 
the issues of assessing risk management and financial stability of the banks and suggested recommended values for a number of balance sheet item relationships, as well as on the basis of regulatory requirements established by the Central Bank of Russia (The Central Bank of the Russian Federation, 2017).

The study used statutory financial reporting data from the Russian banking system as a whole, foreign currency denominated (in ruble equivalent) for the period from 01.10.2010 to 02.01.2019, disaggregated by months. The data for the study were derived from the official website of the Bank of Russia (The Central Bank of the Russian Federation, 2019b). A reference data sample is presented in Table 1.

Table 1. Initial data sample of the banking system balance sheet denominated in foreign currency (in ruble equivalent)

\begin{tabular}{|c|c|c|c|c|c|}
\hline Balance sheet items & $1 / 1 / 11$ & $1 / 1 / 13$ & $1 / 1 / 15$ & $1 / 1 / 17$ & $1 / 1 / 19$ \\
\hline \multicolumn{6}{|c|}{ Foreign currency assets (in ruble equivalent) } \\
\hline Cash, precious metals and stones & 191 & 314 & 1,063 & 520 & 1,025 \\
\hline Accounts with the Bank of Russia and other authorized bodies & 1 & 5 & 513 & 1 & 0 \\
\hline Correspondent accounts with lending institutions & 714 & 1,259 & 2,246 & 1,463 & 1,513 \\
\hline Securities acquired by lending institutions & 950 & 1,276 & 2,814 & 3,541 & 3174 \\
\hline Other equity holding & 1 & 4 & 0 & 0 & 0 \\
\hline Derivative financial instruments & 0 & 0 & 0 & 0 & 0 \\
\hline Credits and other loans, total & 6,062 & 7,231 & 15,411 & 15,900 & 14,574 \\
\hline of them: debt in arrears & 299 & 268 & 502 & 576 & 654 \\
\hline Fixed assets, other real estate, intangible assets and inventories & 0 & 0 & 0 & 0 & 2 \\
\hline Disposition of profits & 0 & 0 & 0 & 0 & 0 \\
\hline Other assets, total & 225 & 321 & 1,245 & 809 & 823 \\
\hline Total assets in foreign currency & 8,144 & 10,410 & 23,292 & 22,234 & 21,112 \\
\hline \multicolumn{6}{|c|}{ Liabilities in foreign currency (in ruble equivalent) } \\
\hline Funds and profits of lending institutions, total (owner's equity) & 0 & 0 & 0 & 0 & 0 \\
\hline $\begin{array}{l}\text { Credits, deposits and other external funds received by lending } \\
\text { institutions from the Bank of Russia }\end{array}$ & 0 & 0 & 1,281 & 689 & 0 \\
\hline Accounts of lending institutions, total & 74 & 133 & 395 & 426 & 441 \\
\hline $\begin{array}{l}\text { Loans, deposits and other funds received from other lending } \\
\text { institutions, total }\end{array}$ & 1,923 & 2,208 & 3,371 & 3,183 & 2,552 \\
\hline Customer funds, total & 5,364 & 7,275 & 15,855 & 16,041 & 16,944 \\
\hline Of these, funds in current accounts & 869 & 1,088 & 2,207 & 2,313 & 2,925 \\
\hline wholesale and retail deposits & 4394 & 6,017 & 13,382 & 13,579 & 13,867 \\
\hline Bonds & 0 & 0 & 0 & 0 & 25 \\
\hline Promissory notes and banking acceptances & 127 & 421 & 379 & 128 & 90 \\
\hline Derivative financial instruments & 0 & 0 & 0 & 0 & 0 \\
\hline Other liabilities, total & 202 & 306 & 1,222 & 749 & 772 \\
\hline Total liabilities in foreign currency & 7,690 & 10,344 & 22,503 & 21,241 & 20,824 \\
\hline
\end{tabular}

Source: The Central Bank of the Russian Federation, 2019b

To determine optimal plan (ideal) indicators of the balance sheet structure, it is proposed to apply one of the most reliable non-linear programming methods-a non-linear generalized down-gradient method built into the package "Search for Solution" in MS Excel (Standard Excel solver - limitations of nonlinear optimization, 2019). Gradient 


\section{ENTREPRENEURSHIP AND SUSTAINABILITY ISSUES}

ISSN 2345-0282 (online) http://jssidoi.org/jesi/

2019 Volume 7 Number 1 (September)

http://doi.org/10.9770/jesi.2019.7.1(34)

methods allow one to find a solution to any smooth nonlinear programming problem in the general case. A disadvantage of these methods is seeking local extremums, not global ones. However, since the search for optimal values of indicators must be carried out in the vicinity of actual indicator values, this problem is removed in the framework of this study.

The final stage of the study involves comparison of the optimal and real (actual) indicators of the balance sheet structure, which would improve the decision-making quality.

As noted previously, it is proposed to use the total profit maximization of the banking system as a decision optimality criterion. To build this criterion function, a method of correlation and regression analysis should be used. A multiple linear regression model of dependence of the banking system's total profit on the indicators of a balance sheet structure denominated in foreign currency is written as:

$$
Z=a_{0}+\sum_{i=1}^{m} a_{i} X_{i}+\sum_{j=1}^{n} b_{j} Y_{j}
$$

where $\mathrm{Z}$ is net profit, billion rubles; $X_{i}$ are asset figures in foreign currency, billion rubles, $Y_{j}$ are liability figures in foreign currency, billion rubles, $a_{0}, a_{i}, b_{j}$ are unknown model parameters.

Stimulants that contribute to increasing bank profits are such balance sheet asset items as securities, loan portfolio, derivative financial instruments, and correspondent accounts with lending institutions. Disposable funds and accounts with the Bank of Russia contribute to an expansion of liquidity; they have no effect on a decline in profits. However, their substantial amount may have an effect of lost profit because the money is kept in the accounts while it could be invested in income-earning assets. All the liability items (except for the item "accounts of lending institutions") are disincentives that reduce the profits. Funds in current accounts and bonds are cheaper resources that, consequently, have a smaller negative impact on profits.

This model was developed using the "Regression" function built into the "Analysis Package" in MS Excel. This function determines unknown parameters of the linear model based on a least squares method, as well as a wide range of statistical measures allowing for evaluation of the developed model quality. When constructing a regression and studying the interrelationships of the observed values of both types of variables, muticollinearity was not studied due to the following considerations:

1) the importance of variables for assessing the balance and a complete macroeconomic picture, as well as the list of the banking system controls with allowance for the foreign exchange risk;

2) the purpose of the article was not to obtain a connection between the observed values of variables and its comprehensive study, but to study and explore balance sheet variables, to control the main balancing variables, and to optimize the criterion function.

To develop a balance sheet optimization model taking into account the currency component, the following notation for determining the balance sheet structure of the banking system was introduced (Table 2). 
Table 2. Indicator notations in the balance sheet structure of the banking system

\begin{tabular}{|c|c|c|c|}
\hline Variable & Indicator & Variable & Indicator \\
\hline $\mathrm{X} 1$ & Cash, precious metals and stones, total & Y1 & $\begin{array}{l}\text { Credits, deposits and other external funds } \\
\text { received by lending institutions from the } \\
\text { Bank of Russia }\end{array}$ \\
\hline $\mathrm{X} 2$ & $\begin{array}{l}\text { Accounts with the Bank of Russia and other } \\
\text { authorized bodies }\end{array}$ & Y2 & Accounts of lending institutions, total \\
\hline $\mathrm{X} 3$ & $\begin{array}{l}\text { Correspondent accounts with lending } \\
\text { institutions, total }\end{array}$ & Y3 & $\begin{array}{l}\text { Loans, deposits and other funds received } \\
\text { from other lending institutions, total }\end{array}$ \\
\hline $\mathrm{X} 4$ & $\begin{array}{l}\text { Securities acquired by lending institutions, } \\
\text { total }\end{array}$ & Y4 & Customer funds, total \\
\hline \multirow{2}{*}{$\mathrm{X} 5$} & \multirow[t]{2}{*}{ Credits and other loans, total } & Y5 & Of these, funds in current accounts \\
\hline & & Y6 & wholesale and retail deposits \\
\hline X6 & of them: debt in arrears & Y7 & Promissory notes and banking acceptances \\
\hline $\mathrm{X} 7$ & Other assets, total & Y8 & Other liabilities, total \\
\hline $\mathrm{X} 8$ & Total assets in foreign currency & Y9 & Total liabilities in foreign currency \\
\hline
\end{tabular}

The choice of the list, type and values of model variables is fully determined by the structure of actual balance sheets in the banking system with regard to requirements of the Bank of Russia for a maximum size of the foreign exchange position (no more than 20\%) in order to develop effective tools for managing assets and liabilities in foreign currency. Part of the variables was excluded from the model due to their degeneracy. Thus, as can be seen from Table 2, there are no indicators such as: "other equity holding"; "derivative financial instruments"; "fixed assets, other real estate, intangible assets, and inventories"; and "disposition of profits" among the asset indicators in foreign currency. Among the liability indicators in foreign currency, there are no indicators such as: "owner's equity", "bonds"; "promissory notes and banking acceptances". This is due to the fact that the value of these indicators was constant (or quasi-constant) and tended to zero throughout the study period from 01.10.2010 to 02.02.2019. As for the indicator "owner's equity", in accordance with the requirements of the Central Bank of Russia, it should be formed only in national currency; therefore, its values were equal to zero in the balance section reflecting foreign exchange operations.

Features of the subject area and strength of financial indicators' relationship within the banking system at the macroeconomic level imply the existence of linear and nonlinear links between balance variables. Most of these links are formalized and interpreted in the model as constraints, with some being considered isolated. The variables included in the calculation (balance ratio) of each other (for example, Y4 includes Y5 and Y6) are not excluded from the model because of the need to preserve invariance in the balance structure, as well as due to the fact that their inclusion does not defy the model logic. 


\section{Results}

An optimal balance sheet structure of the banking system with allowance for foreign exchange risk was determined on the basis of the following nonlinear optimization model in the form of maximum of a target function:

$$
\begin{gathered}
Z=-127,997+0,4253 X 1-0,1991 X 2+0,2970 X 3+0,1659 X 4-0,0408 X 5-0,1964 X 6 \\
+0,0278 X 7-0,2901 Y 1+0,0177 Y 2-0,2968 Y 3+1,9013 Y 4-2,4856 Y 5 \\
-1,8122 Y 6-0,9901 Y 7-0,5926 Y 8 \rightarrow \max (2)
\end{gathered}
$$

under conditions:

$65 \leq \frac{X 5}{X 8} * 100 \leq 70$

$\frac{X 3+X 4+X 5-X 6+X 7}{X 8} * 100 \geq 60$

$\frac{X 6}{X 5} * 100 \leq 5$

$\frac{X 1+X 2+X 3}{X 8} * 100 \geq 12$

$1 \leq \frac{X 5}{Y 6} \leq 1.05$

$5 \leq \frac{X 1+X 2}{Y 6} * 100 \leq 10$

$\frac{X 1+X 2+X 3}{Y 5} * 100 \geq 50$

$10 \leq \frac{X 8-Y 9}{C K} * 100 \leq 20$

$\frac{Y 3}{Y 9} * 100 \leq 20$

$\frac{Y 5}{Y 9} * 100 \leq 30$

$\frac{Y 6}{Y 9} * 100 \geq 50$ 
where $\mathrm{Z}$ is profit, billion rubles; $\mathrm{CK}$ is funds and profits of lending institutions (owner's equity), billion rubles.

To build the target function, the method of correlation and regression analysis was used based on the initial data on the balance sheets of the banking system for the period from 10.01.2010 to 02.01.2019 disaggregated by months (the sample size was 100 points).

The obtained multiple regression equation is adequate as evidenced by sufficiently high values of the coefficients of determination (0.6387) and multiple correlation (0.7992) and also statistically significant in general according to F-test $($ Fcalc $=9.9>$ Ftab $(0.95 ; 15,84)=1.79)$.

Constraint (3) in the proposed model determines the ratio between the loan portfolio and assets ranging from 65 to $70 \%$, as recommended by best banking practices.

Condition (4) restricts the ratio between operational assets and assets to at least $60 \%$, as recommended by best banking practices.

Constraint (5) determines the share of nonperforming loans in the loan portfolio (no more than 5\%), as recommended by banking experts.

Inequality (6) restricts the share of absolutely liquid assets to at least $12 \%$, as recommended by world's experts.

Constraint (7) determines the desired ratio between loans and deposits at a level of no more than 1, as recommended by best banking practices.

Condition (8) limits the ratio between the sum of X1, X2 and deposits at a level of 5 to $10 \%$.

Constraint (9) determines the ratio between liquid assets and funds in settlement accounts at no less than $50 \%$ in accordance with regulatory requirements for current liquidity ratio imposed by the Central bank of Russia.

Condition (10) establishes the foreign exchange position standard within a maximum of $20 \%$, as required by the Central Bank of Russia.

Inequality (11) restricts the ratio between interbank loans and liabilities at a level of no more than $20 \%$, as recommended by best banking practices.

Constraint (12) determines the share of funds in current accounts at no more than $30 \%$, as recommended by best banking practices.

Constraint (13) determines the ratio between deposits and liabilities at a level of at least $50 \%$, as recommended by best banking practices.

The value of owner's equity in this model is set as a priori information in the form of a constant (the actual value as of the date under study), since the owner's equity value is assumed to be an uncontrollable variable. 
Table 3 presents the results of practical application of the model to optimize the balance sheet structure of the Russian banking system and the actual values of respective indicators, as well as the foreign exchange risk standard.

Table 3. Optimization balance sheet structure of the banking system of the Russian Federation

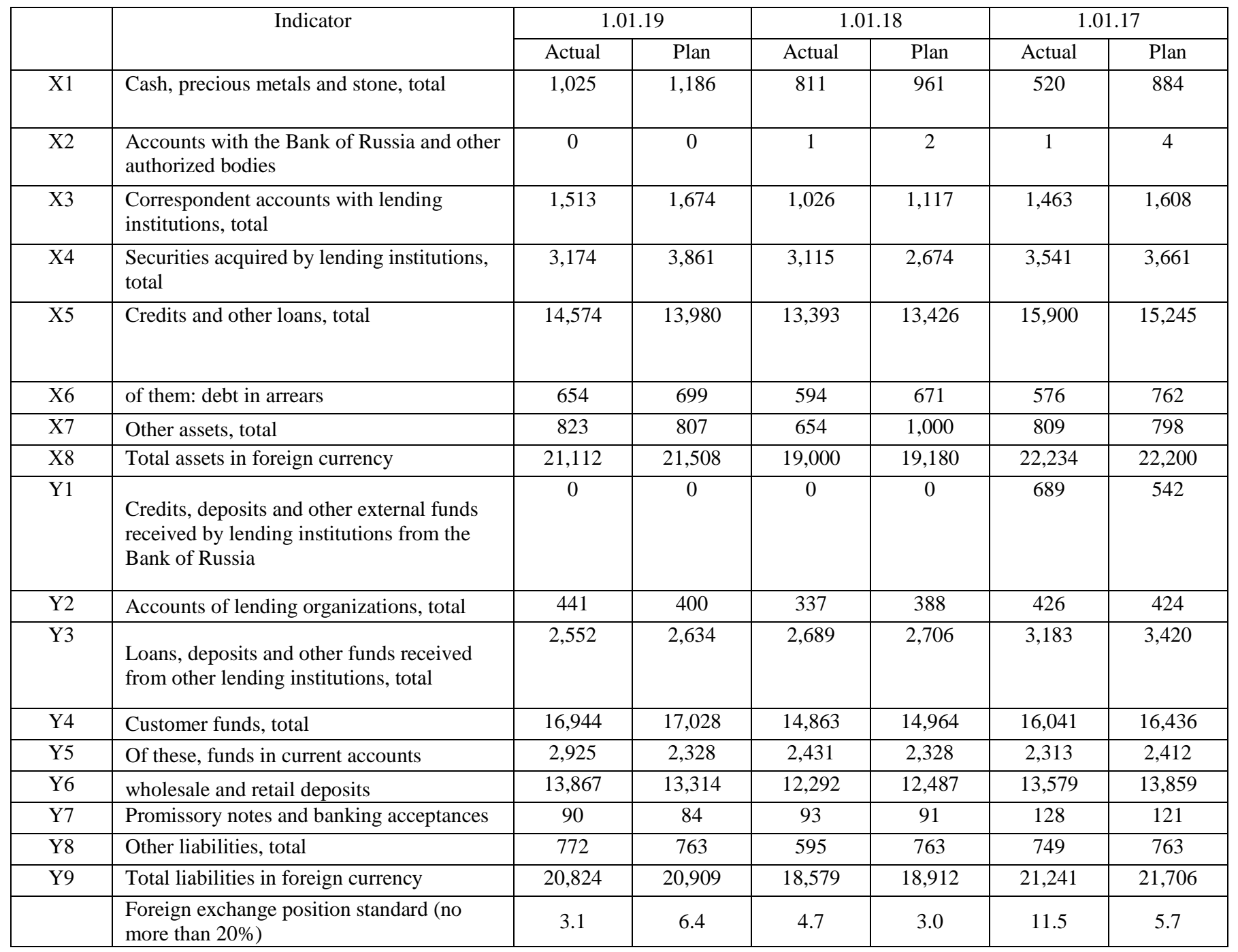

The expected and actual net profit margins as well as return on assets as a result of the mathematical model of optimizing the balance sheet structure of the banking system denominated in foreign currency are shown in Fig. 1. 


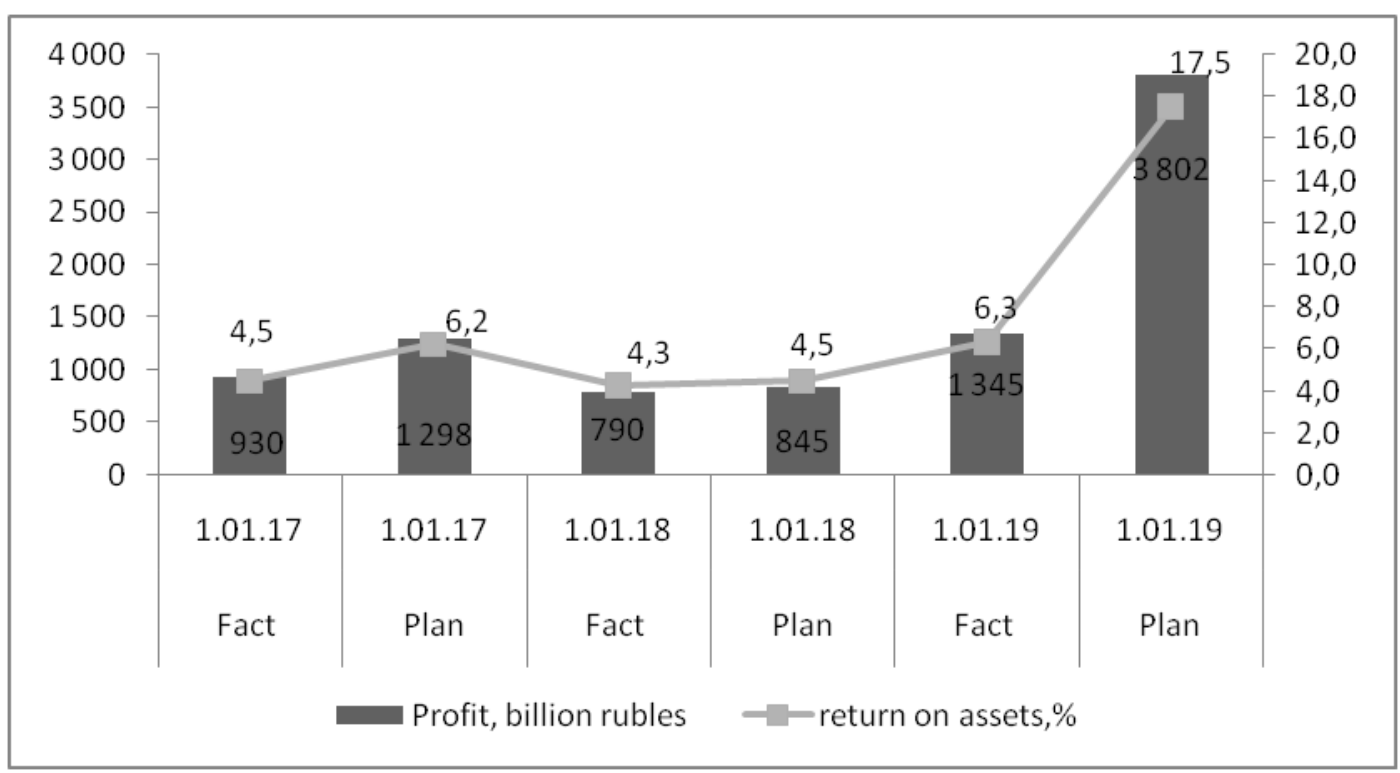

Fig. 1. Expected and actual profit and return on assets of the banking system

\section{Discussion}

The results obtained through the case study during the last three years (from 01.01.2017 to 01.01.2019) indicate that banks could increase the amount of assets and liabilities in foreign currency, which would have a positive effect on the banking system profits. Also, in the optimal model, the banking system liquidity levels would improve due to an increase in cash resources and cash equivalents, as well as the amount in correspondent accounts with other banks as of 01.01.2019 and 01.01.2017. In this event, the loan portfolio size in the planned balance is slightly reduced as of 01.01.2019 and 01.01.2017, while profits increase due to a growing securities portfolio during these periods. In turn, the amount of funds in the optimal balance liabilities as of 01.01.2019 and 01.01.2018 in current accounts that are unstable resources and can be withdrawn at any time is declining. A decreased deposit portfolio of legal entities and individuals as of January 1, 2019 compared to the actual values would have allowed banks to increase their income by reducing the cost of interest on deposits. According to the research results, it can be seen from Fig. 1 that the expected profit and return on assets at the optimal structure of the balance sheet in a foreign currency is significantly higher than that actually received. Also, the levels of foreign exchange risk (the foreign exchange position standard) in 2017-2018 in the planning periods decrease and remain within the normal range in 2019 despite some growth. It is important to note that the increase in assets and liabilities in foreign currency as of 01.01.2019 has affected a growth in the foreign exchange position by 3.5 percentage points (up to 6.4\%) and in the return on assets-by 11.2 percentage points (to 17.5\%). Such a significant increase in the expected profit and return on assets in 2019 was determined by a plummeting of the dollar exchange rate by $21.7 \%$ compared with the previous year (The Central Bank of the Russian Federation, 2019a). In other words, a controlled foreign exchange risk when the dollar keeps rising can improve the profitability of banking institutions. Thus, optimization of the balance sheet in the Russian banking system, denominated in foreign exchange, would maximize profits at a controlled level of currency exposure, which indicates that the goal of research has been achieved.

The point of the study was an attempt made to optimize the balance sheet structure, firstly, at the macro level (using the example of the banking system as a whole) and, secondly, only in the part of the banking system balance that reflects foreign currency transactions. All the previous studies discussed in Literature review had mainly affected the micro-level (individual banking institutions) and did not consider the foreign exchange risk management. Unfortunately, the paper does not consider the possibility of optimizing the structure of assets and 


\section{ENTREPRENEURSHIP AND SUSTAINABILITY ISSUES}

ISSN 2345-0282 (online) http://jssidoi.org/jesi/ 2019 Volume 7 Number 1 (September) http://doi.org/10.9770/jesi.2019.7.1(34)

liabilities of the banking system, expressed in foreign currency, in a downturn. This, in our opinion, should serve as a line of further research on this subject.

The results of the study may find practical use in improving the foreign exchange risk management policies at the level of banking system, pursued by the Central Bank of Russia. Optimization of the balance sheet structure of the banking system, taking into account then foreign exchange risk, would allow for maximization of profits in the context of currency rate volatility that has recently become more frequent and would reduce the number of unprofitable banks. The proposed approach to optimizing the balance sheet structure through the cases study of the banking system can also be adapted for individual banking institutions.

\section{Conclusion}

In this study, a mathematical model was developed to optimize the balance sheet structure of the Russian banking system. The model presented in the framework of this study has made it possible to determine such a structure of assets in the banking system and portfolio of liabilities that would help to ensure a controlled foreign exchange risk dimension with an increase in the dollar exchange rate. Practical implementation of the developed mathematical model to optimize the balance sheet structure allows one to identify a level of plan indicators in the balance sheet structure that would ensure excess of the actual level of bank financial stability indicators: profit and return on assets. The proposed approach is an effective and universal tool for managing foreign exchange risks in the Russian banking system and for developing timely preventive measures to reduce them in the framework of the tactical and strategic banking activities. Also, this mathematical optimization model can be used as a tool for monitoring and assessing bank performance efficiency. Some major advantages of this approach are dynamic programming and the possibility to use various constraints for structural balance sheet indicators in compliance with modern requirements for financial security of banking institutions and increasing the correlation between balance sheet items. The proposed mathematical model for optimizing the balance sheet structure can serve as a guide for the Central Bank of Russia in decision-making and developing strategies in various economic circumstances. In addition, the proposed approach can serve as a tool for individual banking institutions used to plan a bank's future development strategy.

\section{References}

Agarana, M. C.; Bishop, S. A.; Odetunmibi, O. A. 2014. Optimization of banks loan portfolio management using goal programming technique, International Journal of Research in Applied, Natural, Social Sciences 2(8): 43-52.

Alhumaidah, F. 2015. Asset-liability management for reserves under liquidity constraints: The case of Saudi Arabia, Procedia Economics and Finance 29: 17-40. https://doi.org/10.1016/S2212-5671(15)01112-0

Alizadeh, M.; Asadi, A.; David, A. R. 2016. Fuzzy optimization. The 8th International Conference of Iranian Operations Research Society, Mashhad, Iran. Mashhad: Ferdowsi University of Mashhad.

Arewa, A.; Owoputi, J. A.; Torbira, L. L. 2013. Financial statement management, liability reduction and asset accumulation: An application of goal programming model to a Nigerian bank, International Journal of Financial Research 4(4): 83-90. https://doi.org/10.5430/ijfr.v4n4p83

Asian Development Bank. 2015. Financial soundness indicators for financial sector stability. A tale of three Asian countries. Retrieved from https://www.adb.org/sites/default/files/publication/173687/fsi-3-asian-countries.pdf 


\section{ENTREPRENEURSHIP AND SUSTAINABILITY ISSUES}

ISSN 2345-0282 (online) http://jssidoi.org/jesi/ 2019 Volume 7 Number 1 (September) http://doi.org/10.9770/jesi.2019.7.1(34)

Azizi, S.; Neisy, A. 2017. Mathematic modelling and optimization of bank asset and liability by using fractional goal programing approach, International Journal of Modeling and Optimization 7(2): 85-91. http://dx.doi.org/10.7763/IJMO.2017.V7.564

Bolotov, D. 2013a. Implementation model of the automatic generation the final amount of commissions in international banking payments, Journal of Contemporary Economics Issues 1. https://doi.org/10.24194/11306

Bolotov, D. 2013b. Methodical approaches to determination of economic effect of using optimization models to reduce the costs of implementing international bank transfers, Journal of Contemporary Economics Issues 3. https://doi.org/10.24194/31303

Chunikhin, S. A.; Kuzmin, E. A.; Pushkareva, L. V. 2019. Studying the banking industry's stability through market concentration indices, Entrepreneurship and Sustainability Issues 6(4): 1663-1679. http://doi.org/10.9770/jesi.2019.6.4(8)

Dudka, A. B. 2006. Approaches to managing the structure of assets and liabilities of a commercial bank, Herald of Omsk University. Series "Economics" 2: 132-137. Retrieved from

https://cyberleninka.ru/search?q=\%D0\%94\%D1\%83\%D0\%B4\%D0\%BA\%D0\%B0\%20\%D0\%90.\%D0\%91

Ebrahimi, M. 2010. Mathematical modeling asset management in commercial bank debt using goal programming. Tehran: Published by University of Al-Zahra, 365p.

Halim, B. A.; Karim, H. A.; Fahami, N. A.; Mahad, N. F.; Nordin, S. K. S.; Hassan, N. 2015. Bank financial statement management using a goal programming model, Procedia - Social and Behavioral Sciences 211: 498-504. https://doi.org/10.1016/j.sbspro.2015.11.066

Hilkevics, S.; Semakina, V. 2019. The classification and comparison of business ratios analysis methods, Insights into Regional Development 1(1): 48-57. https://doi.org/10.9770/ird.2019.1.1(4)

Islami, B. G.; Mehregan, M; Gholami, P. 2011. Optimal management of assets in banks using fuzzy hierarchical analysis and planning, Quarterly Financial Engineering and Management Portfolios 9: 23-44.

Izadi, N. N.; Ghandahar, M.; Abedini, A.; Moradi A. 2012. Capital adequacy ratios as a function function in modeling asset and liability management of banks (Case study: Tejarat Bank), Journal of Accounting and Financial Management 9: 130-152.

Karkowska, R. (Ed.). 2014. Challenges to financial stability - perspective, models and policies. Craiova: Published by ASERS Publishing.

Khalili, I. M. 2007. Best optimal stock selection using goal programming, Economics Bulletin 6: 37-64.

Khazri, B. S.; Dehghan, A.; Aslizadeh, A. 2018. Design and optimization of the asset and liability model based on the multiple-objective decision-making view, Industrial Engineering \& Management Systems 17(2): 311-317. https://doi.org/10.7232/iems.2018.17.2.311

Kunitsyna, N.; Britchenko, I.; Kunitsyn, I. 2018. Reputational risks, value of losses and financial sustainability of commercial banks, Entrepreneurship and Sustainability Issues 5(4): 943-955. http://doi.org/10.9770/jesi.2018.5.4(17)

Laeven, L.; Valencia, F. 2018, September 14. Systemic banking crises revisited. International Monetary Fund, Retrieved from https://www.imf.org/en/Publications/WP/Issues/2018/09/14/Systemic-Banking-Crises-Revisited-46232

Mehrabi, L. 2014. Asset-liability management in Islamic banks, The Central Banks Quarterly 4: 127-144.

Mehri, M.; Jamshidinavid, B. 2015. Designing a mathematical model of asset and liability management using goal programming (Case study: Eghtesad-e- Novin Bank), GMP Review 18(3): 186-195.

Mohammadi, R.; Sherafati, M. 2015. Optimization of bank liquidity management using goal programming and fuzzy AHP, Research Journal of Recent Sciences 4(6): 53-61. Retrieved from http://www.isca.in/rjrs/archive/v4/i6/9.ISCA-RJRS-2014-226.pdf

Moody's Investors Service. 2009. Moody's rating symbols \& definitions. Retrieved from https://www.moodys.com/sites/products/productattachments/2007100000528403.pdf

Oleksyk, P. 2018. Financial Reporting Analyses in Preparation of Dividend Payments in Polish Banks, Transformations in Business \& Economics 17, 2A (44A): 309-324. 


\section{ENTREPRENEURSHIP AND SUSTAINABILITY ISSUES}

ISSN 2345-0282 (online) http://jssidoi.org/jesi/ 2019 Volume 7 Number 1 (September) http://doi.org/10.9770/jesi.2019.7.1(34)

Pitel, L.; Arnold, M. 2018. Turkish business feels the pain of currency crisis. Lira's tumble hits companies that borrowed in euros and dollars for years. Financial Times, Retrieved from https://www.ft.com/content/0661a1b0-9f08-11e8-85da-eeb7a9ce36e4

Saksonova, S. 2013. Approaches to improving asset structure management in commercial banks, Procedia - Social and Behavioral Sciences 99: 877-885. https://doi.org/10.1016/j.sbspro.2013.10.560

Standard Excel solver - limitations of nonlinear optimization. 2019. Frontline Solvers, Retrieved from https://www.solver.com/standardexcel-solver-limitations-nonlinear-optimization

Teresienè, D. 2018. Performance measurement issues in central banks, Entrepreneurship and Sustainability Issues 6(1): 176-189. http://doi.org/10.9770/jesi.2018.6.1(12)

The Central Bank of the Russian Federation. 2017, June 28. Bank of Russia instruction No. 180-I "On mandatory bank standards". Retrieved from http://base.garant.ru/71721584/\#ixzz5oyRM3S30

The Central Bank of the Russian Federation. 2019a. Currency exchange rate database. Retrieved from http://www.cbr.ru/currency_base/

The Central Bank of the Russian Federation. 2019b. Performance indicators of credit institutions. Retrieved from https://www.cbr.ru/Content/Document/File/48169/bsr_2008.pdf

Tvaronavičienė, M.; Masood, O.; Javaria, K. 2018. Preconditions of the Eurozone economic security: how to overcome liquidity risk and cost inefficiency in leading banks of UK and Germany, Polish Journal of Management Studies 18(1): 418-427. http://doi.org/10.17512/pjms.2018.18.1.31

Umarova, K. A.; Idirisova, A. T. 2015. Asset and liability management at a commercial bank, Innovative Science 5: 110-113. Retrieved from https://cyberleninka.ru/article/n/upravlenie-aktivami-i-passivami-v-kommercheskom-banke

Xu, T. T.; Hu, K.; Das, U. S. 2019, January 11. Bank profitability and financial stability. International Monetary Fund, Retrieved from https://www.imf.org/en/Publications/WP/Issues/2019/01/11/Bank-Profitability-and-Financial-Stability-46470

Karine BARMUTA is a Doctor of Economic Sciences, Head of the Department of Economics and Management, Don State Technical University. Research interests: enterprise development management, organizations innovation and investment activity, organization crisis management.

ORCID ID: orcid.org/0000-0001-5460-4086

Vadim PONKRATOV is a Candidate of Economic Sciences, Director of the Financial Policy Center of the Public Finance Department, Financial University under the Government of the Russian Federation. Research interests: state financial policy, evaluation of its effectiveness; management of oil and gas budget revenues, strategies for the formation and use of sovereign funds resources; natural rent and instruments of its withdrawal; tools of state financial incentives for economic development.

ORCID ID: orcid.org/0000-0001-7706-5011

Maksim MARAMYGIN is a Doctor of Economic Sciences, Professor of the Finance, Money Circulation and Credit Department, Director of the Institute of Finance and Law of the Ural State University of Economics. Research interests: monetary policy, bank risks, money theory, investments.

ORCID ID: orcid.org/0000-0003-3416-775X 


\section{ENTREPRENEURSHIP AND SUSTAINABILITY ISSUES}

ISSN 2345-0282 (online) http://jssidoi.org/jesi/ 2019 Volume 7 Number 1 (September) http://doi.org/10.9770/jesi.2019.7.1(34)

Nikolay KUZNETSOV is a Doctor of Economic Sciences, Candidate of Technical Sciences, Director of the Economics and Finance Institute of the State University of Management. Research interests: building systems of financial and economic management of enterprises; financial and strategic management, financial analysis, economic and mathematical modeling and forecasting.

ORCID ID: orcid.org/0000-0001-9897-1531

Vitali IVLEV is a Doctor of Philosophical Sciences, Professor, Head of the Philosophy Department of the National Research University, Bauman Moscow State Technical University. Research interests: methodology, ecology, logic.

ORCID ID: orcid.org/0000-0002-1674-2071

Marina IVLEVA is a Candidate of Philosophical Sciences, Associate Professor. Research interests: economics, environmental ethics, organizational culture.

ORCID ID: orcid.org/0000-0002-5134-7595

Register for an ORCID ID:

https://orcid.org/register

Copyright (C) 2019 by author(s) and VsI Entrepreneurship and Sustainability Center

This work is licensed under the Creative Commons Attribution International License (CC BY).

http://creativecommons.org/licenses/by/4.0/

\section{(c) (i) Open Access}

